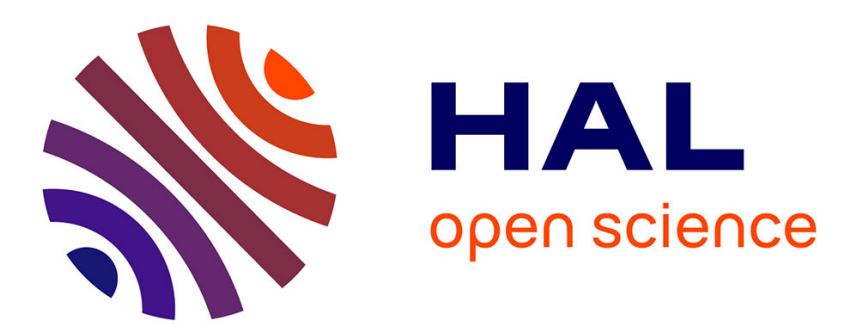

\title{
Are Borders More Easily Crossed Today? The Paradox of Contemporary Trans-border Mobility in the Andes
} Anne-Laure Amilhat Szary

\section{To cite this version:}

Anne-Laure Amilhat Szary. Are Borders More Easily Crossed Today? The Paradox of Contemporary Trans-border Mobility in the Andes. Geopolitics, 2007, Latin American Borders, 12 (1), pp.1-18. 10.1080/14650040601031065 . halshs-00252985

\section{HAL Id: halshs-00252985 \\ https://shs.hal.science/halshs-00252985}

Submitted on 12 Feb 2008

HAL is a multi-disciplinary open access archive for the deposit and dissemination of scientific research documents, whether they are published or not. The documents may come from teaching and research institutions in France or abroad, or from public or private research centers.
L'archive ouverte pluridisciplinaire HAL, est destinée au dépôt et à la diffusion de documents scientifiques de niveau recherche, publiés ou non, émanant des établissements d'enseignement et de recherche français ou étrangers, des laboratoires publics ou privés.

\section{(c)(1)}

Distributed under a Creative Commons Attribution| 4.0 International License 
Anne-Laure AMILHAT SZARY

Université Grenoble1 / PACTE-Territoires, UMR 5194

14 bis avenue Marie Reynoard, 38100 Grenoble

Anne-Laure.Amilhat@ujf-grenoble.fr

Tél 33476822080 / Fax : 33476822001

\title{
Are Borders More Easily Crossed Today? The Paradox of Contemporary Trans-border Mobility in the Andes
}

\section{Anne-Laure Amilhat Szary}

The results of this paper are drawn from an ECOS / CONICYT cooperation programme $\left(n^{\circ}\right.$ $\mathrm{CO} 3 \mathrm{HO} 4$ / $\mathrm{AO} \mathrm{OHO4}$ )

\section{KEY WORDS}

Chile-Bolivia Conflict, Trans-Andean Region; regional stakeholders, mobility; transportation; borderlands, globalisation.

\begin{abstract}
In a globalised world, borders are commonly said to be loosing their 'fencing' function and allowing more flexibility of all kinds. This process can either be viewed as the cause or the consequence of the development of all kinds of circulations (goods, capitals, ideas, people). A closer analysis reveals that this phenomenon is commonly not as new as it appears, since borders have seldom been really impermeable. In Latin America, the historical process of border design over a very scarcely dense territory confirms this trend and a closer analysis of the Southern Andes context reveals indeed that the closing up of international boundaries is quite recent. This paradoxical historical data helps explain both the current geopolitical map of the region (which is far more complex than the juxtaposition inter-state conflictive relations) and the status of differentiated mobility control in the evolution of borderlands.
\end{abstract}

\section{INTRODUCTION}

In the past decade, borders were commonly said to be losing their 'fencing' function and allowing more flexibility of all kinds; thus, the movement of people and merchandise should have been growing as a result of the 'opening' of borders. However, since 11 September 2001, boundary enforcement has intensified along various boundaries, mainly where political limits coincide with some of the planet's main economic gaps (United States/Mexico, external EU borders), and contributed to the surroundings of the world's most powerful countries. The USMexico divide is now generally used to illustrate the paradox of the existence of barricaded 
borders in the heart of a borderless economy, some of the conclusions being extended to the evolution of European borders in the Schengen context. ${ }^{1}$ The chiasmus has been thoroughly underlined, allowing its generalization as a pattern of contemporary geopolitics - the "variable permeability of borders' defined as 'one of the major contradictions of the contemporary world', ${ }^{2}$ leading to the differentiation of external/internal boundaries that are essential in the European context. Simultaneous opening and closing of borders are thus both a historical paradox often found at certain times over the centuries and a political trend that can be identified elsewhere today. Yet the fact that this phenomenon can be witnessed everywhere around the world does not mean that it is homogeneous.

The reality of the border situation in the Andes differs notably from this overall pattern. On the one hand, despite recent construction of new transport infrastructures, mobility patterns have not reached the levels that occurred during periods of intense trans-Andean contact and exchange. On the other, this Latin American region does not seem to be suffering too much from post-2001 trauma and reveals current interesting efforts in border facilitation. If the paradox of trans-border mobility is by no means exclusive to the Andes, some of its characteristics appear original and only comparable with other mountain situations, as shown by the author's comparison of research results with other European situations.

Following World War II, on the eve of the contemporary period of integration, Roger Dion asserted: 'Whether or not corresponding with natural frontiers, the linear frontiers of Europe have become terrible realities'. A posteriori reading of this fundamental text stresses the importance of context for understanding border phenomena. The Andes was a contact zone in pre-Hispanic times but was split by the borders of the nation-states that arose in the $19^{\text {th }}$ century. Still, trade continued throughout the $19^{\text {th }}$ century, as the mining resources (silver, nitrates, copper) of the Atacama region were discovered and exploited, re-initiating contact with neighbouring Argentinian and Bolivian provinces. In fact, it was only during the 1970s and 1980s that the dictatorships that ruled the countries of the Andean region simultaneously 
succeeded in 'closing' the borders, in some cases, by laying land mines along the borders. The entry of most of the economies in the Andean zone into the globalisation process has induced many changes in the status of borders in this part of the continent: trans-Andean roads and gas pipelines are being built very quickly to favour exports (and imports) and much of the regional political rhetoric is about integration and trans-border regionalism. This rapid chronology of change points out the essential role of state power in the definition of border regimes. Do closed borders necessarily rhyme with authoritarian regimes, and vice-versa? A thorough study of the evolution of state power during the post-dictatorship transition regimes in South America allows a qualification of this rapid equivalence.

In the past decade, studies of the evolution of the central Andes have shown that personal mobility did not grow at the rate predicted by integration supporters, but in many instances decreased (at least for inhabitants of areas located close to a border). The same paradox has been observed in some European border regions: freedom of passage does not seem to induce a direct rise in trans-border movements. To determine historical trends (toward closing or opening borders), it is necessary to analyse for whom the border is closing and for whom it is opening, depending on the interests at stake. To this end, it is important to confront the political discourse that develops at a local scale and the corresponding spatial practices. At a regional or national scale, however, because conclusions can change radically, they must be combined with a social approach: the mobility patterns of the elites were different in the present study zone. The difference between trans-border mobility and border mobilisation, which can be defined as the instrumentalisation that can be made of the spatial 'opening' of borders, will be defined and analysed. This analysis confronts the more subtle subjective forces that may motivate the opening or closing of borders, including ideology and the democratic debate.

\section{CONFLICTIVE NATIONALISMS, CONSENSUAL BORDERLINES?}


A world overview of border conflicts leaves Latin American far behind. With the exception of the recent Perú-Ecuador war in the Condor Cordillera, the continent, whether considered as a whole or reduced to its Andean part, does not seem to be home to many substantive international territorial claims, although locally, some old disputes on maritime possessions or land portions cause ongoing interference In bilateral foreign affairs. One could even exclude the Patagonian discussions from the debate, knowing that what is at stake in the various delimitation problems of this Finis Terrae is the potential influence of both Chile and Argentina over the Antarctic continent (their respective influence zones are calculated on the basis of the projected border coordinates). The 'gas war', as the riots that took place in Bolivia in October 2003 were called and that led former president de la Gonzalez de Lozada to resign and flee the country, have somehow reactivated the local geopolitical debate.

It is commonly thought that most Latin American borders are a result of the breakdown of the Spanish Empire at the beginning of the $19^{\text {th }}$ century, when many of the colonial administrative limits between vice-kingdoms served as a basis for drawing up the new international borders. The dominant 'Uti Possidetis' ('you will possess what you possessed') doctrine, a concept of international law that defines borders of newly sovereign states on the basis of their previous administrative frontiers, was generally respected although its results were more complex than originally thought. According to a detailed analysis, ${ }^{4}$ only $30 \%$ of South American international boundaries were drawn on pre- $19^{\text {th }}$ century limits and another $10 \%$ of them dated from after the opening of the Panama Canal (1914). This implies that $60 \%$ were defined outside of these time lines and were negotiated by the newly independent states and, thus, only partly result from the colonial legacy. The gap between the doctrine and its application is linked to four factors. Colonial limits were indeed interwoven: administrative, religious or judicial lines coexisted without necessarily fitting exactly. The hierarchy of the colonial demarcation was far from respected: present-day boundaries often follow what used to be sub-delimitations of Spanish territory (viceroyalties, provinces, 
gobernaciones and comarcas). Furthermore, colonial limits were seldom indicated by milestones, and their subsequent marking led to numerous disputes. Lastly, it must be remembered that this rule did not apply to the Portuguese empire, which had a different decolonization process.

In this judicial context, the territorial wars of the following century did not originate from local delimitation problems, but rather from clashes of interest between the more powerful countries, Brazil and Argentina mostly, which resulted in the creation of Uruguay on one hand and the theft of a great deal of Bolivian land on the other (the Chaco War). The Pacific War, in which Chile fought against a coalition consisting of Perú and Bolivia between 1879 and $1883-84$, can be interpreted according to the same criteria. Great Britain financed Chile's war effort, thereby helping Chile become a regional power since the war allowed Chile to claim the rich subsoil of the Atacama desert (nitrates, copper and non-mineral resources) and also serving British interests in the mining industry.

The outcome of the Pacific War was the loss of one province from each of the coalition members to the victorious Chileans, whose northern border was extended some 700 kilometres northward (today's regions of Tarapacá and Antofagasta belonged to Perú and Bolivia, respectively [see Figure 1]). Chile negotiated a separate peace agreement with each country. With Perú, the Ancón Treaty ended the conflict in 1883 but its implementation failed in 1926. However, an agreement, reached with the help of a US mediator, led to a final peace treaty being ratified in a 1929 referendum, whereby the Arica province passed to Chile while the Tacna province remained Peruvian. With Bolivia, although hostilities ceased in 1884, a treaty was not signed until 1904. Diplomatic relations were restored at the same time, only to be interrupted again twice, in 1962 and 1978; they have yet to be re-established. ${ }^{5}$ Although Argentina did not take part in this conflict, it was directly affected by it. Turmoil in the north meant the Chilean armies were engaged there, so Argentina launched a vast campaign in the south, opening the path to its domination over Patagonia; then, regional diplomatic 
negotiation pressured Bolivia to accept the transfer of some of its territories to its southern neighbours. However, the destiny of the four protagonists (Chile, Perú, Bolivia and Argentina) is interwoven, since the documents signed in Ancón stipulated that no decision concerning exterritorial possessions of Perú could be taken without consulting its government and, thus, no territory in this area could be ceded to Bolivia by Chile without Peruvian agreement. This made the situation more complex, as will be seen, since, after losing its access to the sea, Bolivia was guaranteed access to the harbour at Arica in northern Chile, an ex-Peruvian possession (by a railway between La Paz and Arica contemplated in the 1904 treaty, then by a paved road since 1996) but without any possibility of extended territorial control over a corresponding 'corridor' without Perú's confirmation of any Chilean proposal.

Figure 1: The Historical Border Game in the Central Andes 


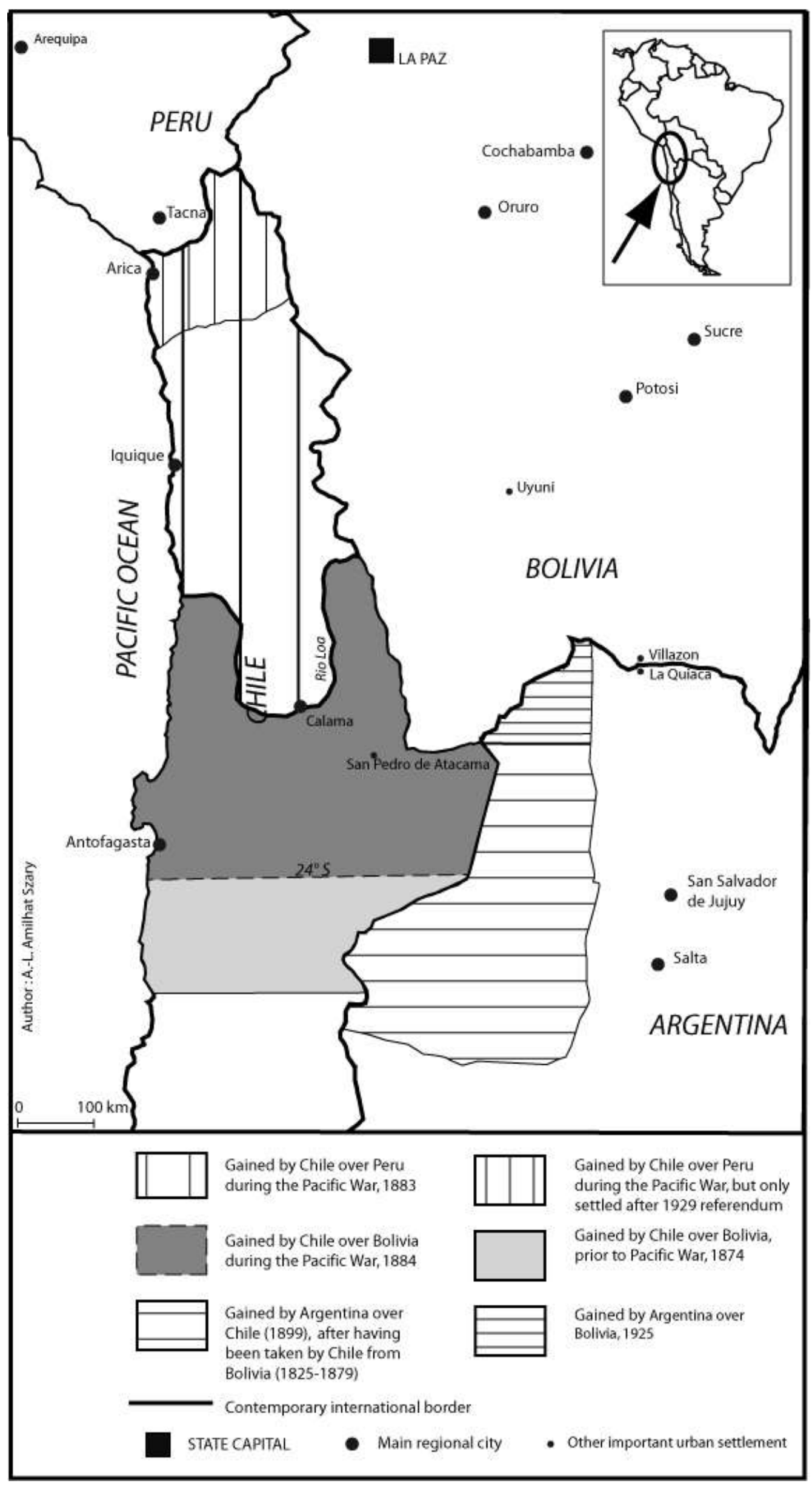


Despite this complex diplomatic situation, a whole set of regional exchanges has developed in the past 20 years. Based on economic rationality, they are operated by local and regional entrepreneurs together with local territorial representatives who have not been hampered by the absence of diplomatic relations at a higher level. Regional encounters (trade fairs, infrastructure commissions, bilateral committees) multiplied in the $1990 \mathrm{~s}$ and at the beginning of the $21^{\text {st }}$ century. This local dynamic process of "paradiplomacy" was echoed in the pragmatic Chilean foreign policy of the 1990s, ${ }^{7}$ which resolutely adopted a strategy of 'open regionalism'. The latter has been defined and advocated by APEC (Asia-Pacific Economic Cooperation) in its founding declaration and widely advocated by the IMF and other global institutions, although amended by the ECLA (Economic Commission for Latin America and the Caribbean), which has promoted a social counterpart to the commercial process. ${ }^{8}$ This involves an effort to lead a continental integration that, rather than close the region to outside commerce, would accelerate a policy of trade liberalisation. In this perspective, Chile has successfully developed a very open partnership policy: it is member of APEC and an associate member of MERCOSUR. However, it does not feel that these integration agreements bar it from negotiating directly with others, as shown by its various bilateral agreements. ${ }^{9}$ This ability to mix bilateral, pluri-lateral and multilateral free-trade agreements has been characterized as a 'lateral trade policy' on behalf of Chile. This multidimensional strategy based on multiple economic contacts at continental and neighbouring levels has had a great impact on foreign affairs and has reinforced political alliances. ${ }^{10}$ Most often, Chilean stakeholders have initiated these contacts. Toward Bolivia, for example, as unbalanced as the negotiation may seem given the investment capacity of each side, this did happen and the pro-integration lobby was particularly strong on the eve of the 'gas war'"1 . The fact that in 2002, in deciding on the route for a new gas pipeline to allow the broadening of the country's potential export markets, former president Gonzalez de Lozada arbitrated in favour of the Chilean harbour option rather than the Peruvian option 
paradoxically and retrospectively proves these commercial regional dynamics. In their bid to improve their opportunities of exporting gas from the Tarija gas fields to the United States via the Pacific coast, Bolivian entrepreneurs from Santa Cruz and Cochabamba developed longstanding working relationships with Chilean businessmen. In a way, this decision marked the victory of a pragmatic vision of 'territory', defined here as an economic exchange zone.

The local population, including those who live near the border, has not yet been mentioned; this is significant because it has long been thought that the opinions of local people were not worth taking into account. Interestingly enough, this has occurred in a country in which indigenous people are the majority, that is, Bolivia, and in its neighbour, Chile, where indigenous people represent only small minorities that have been subjected to an aggressive 'nationalisation' process. The central Altiplano Andes are mainly the territory of the Aymaras, an ethnic group that became politically structured in ancient times (during the Tiwanaku Era, circa 1000 AD), before falling under the external domination of others, notably the Incas (originating from the Quechua area). Their cultural zone was subsequently fragmented by national borders in the $19^{\text {th }}$ century, leaving the Aymaras as Chilean, Peruvian and Bolivian citizens. The smallest group remained in Chile, where its members' integration into the nation has been more complete (though not always willing); their traditions were threatened by state educational policies and by the communal demarcation of mountain territories throughout the $20^{\text {th }}$ century. ${ }^{12}$ In Bolivia, the Aymaras represent the main ethnic group, although they have had little political representation. Since the 1990s, however, they have renewed their claims and have achieved new areas of representation on a national scale (not only through the Aymara leader Felipe Quispe but also through the inclusion of ethnic claims in the struggle of Evo Morales, the leader of the Movement Towards Socialism [MAS]). While the economically favoured entrepreneurs worked to integrate the periphery, the Aymaras have worked to conquer public space on a national level. A strong rural exodus boosted the Aymara population in and around La Paz and contributed immensely to their 
political emergence; they no longer represented marginal mountain populations, their claims had gained political influence, and their territorial vision could be linked with that of the nation. This may explain the social upheaval that immediately followed the decision to launch a gas pipeline through Chile, although it ignores the drug problem (growing coca leaves is a major issue for Aymara peasants) and the debate on the economic model (the essential question from the start of the conflict was whether gas should be exported, making the route of the pipeline a secondary issue). The goal of this paper is to illustrate a rival conception of territory, which is, at first glance, less global and post-modern than the previous conception we have found and analysed in this region.

Restrictions on movement in the area may exist, but most of the time they are minimised in favour of the opening process that is supposed to be occurring. However, the fluidity of movement around a border is a very subjective phenomenon. Although currently the borders of the Central Andes are certainly opening up, this is quite different from what took place in the previous period.

\section{THE RECENT CLOSURE OF TRADITIONAL PERMEABLE BORDERS}

The 'gas war' refocused attention on the difference between the positions of Chile and Bolivia on their common border. Despite the unsettled character of the post-war territorial conflict, the borderland had long remained what it had always been, that is, a zone of movement, a line that could easily be crossed. The international border winds through the Altiplano, the relatively flat highlands of the Andes, about 4,000 metres above sea level, where a multitude of highaltitude volcanoes $(5,000$ to 6,000 metres or more) are situated. In the traditional schemes of land occupation, this high plateau has never been isolated. In pre-Colombian times, Andean populations had a close relationship with the populations of the neighbouring environments of the Pacific Coast and the Amazonian Selva (dense forest). Not only did they exchange goods with them, but colonies of mountain populations often settled in areas situated below or above them (at lower altitudes, they found fish, fruit, wood, etc.; at higher altitudes, there were 
pastures, mines, etc.). This form of space occupation was described at the beginning of the $20^{\text {th }}$ century as a complementary use of habitats that allowed Andean people to live according to an 'archipelagic' pattern. ${ }^{13}$

In the colonial process, the conquest of land was aimed at controlling and exploiting the soil. The dramatic decline of the indigenous populations that followed the Spaniards' arrival involved tight spatial control of the survivors. This signified a major change in the life of the Andean populations, who were assigned to fixed places of residence in order to control the workforce they represented and ensure their submission to taxation. Most of the 'Indians' were grouped in native villages called reducciones, a significant Spanish term that qualified the reduction of their life horizon. However, the ability of these populations to be mobile was so great that it survived, with adaptations, of course, ${ }^{14}$ and even the imposition of international boundaries did not fully achieve the desired settlement process. The native groups were generally not included as full citizens of the emerging states at the beginning of the $19^{\text {th }}$ century. Although constitutional acts recognized their rights as individuals in nation-states 'in progress', the administrative control of the areas where they lived was flexible enough to authorize different approaches to settlement. Many native groups continued to exercise seasonal trans-habitat mobility, together with everyday local movement; a community's central settlement was never located at one end of its territory but generally at the limit between two habitats, allowing the use of higher and lower land resources, according to the group's needs.

This pattern is easily applied to the area being analysed. Archaeologists have confirmed that complementariness existed between coast, mountain and forest groups since the prehistoric period of the hunter-gatherers (4000-5000 BC). Indeed, some groups were already undertaking seasonal movements that followed certain regular routes, thus defining 'exploratory' mobilities. Llama caravans were the basis of the trade that developed within the large Tiwanaku and Inca empires. ${ }^{15}$ After the Spanish Conquest at the beginning of the $16^{\text {th }}$ 
century, these regional movements did not stop, despite the colonial power's effort to settle the indigenous population. The Empire's main resource was the silver mines of Potosi, located on the central Altiplano; the tons of silver that were extracted from the magic mountain were exported through the harbours at Arica and Cobija, which today are in Chile, south of the border with Perú. Thus, commercial travelling took place during the colonial era, although it declined temporarily when the silver mines reduced their production and borders were drawn. After nitrate resources were discovered in the Atacama Desert at the beginning of the $19^{\text {th }}$ century, a new era of mobility opened up. ${ }^{16}$ The Pacific piedmont became the centre of all traffic ${ }^{17}$; men converged to work in the new mines (salitreras) and in the coastal cities that emerged to accompany this development, and all needed to be fed (vegetables and cereals came from the pre-Cordillera valleys and the Altiplano, while meat-in the form of cattle drives - came from Argentina). The authorities involved preferred to abandon their bordercontrol prerogatives in order to facilitate the traffic on which the regional economic boom was based. $^{18}$

The insight into the history of this subregion reveals that Andean borders have only been shut down very recently - throughout the $20^{\text {th }}$ century - a closure that may be attributed to a conjunction of economic and political factors. The nitrates' crisis of the $1930 \mathrm{~s}^{19}$ drastically reduced traffic volumes in the area and the subsequent rise of nationalist regimes confirmed the trend. Although it began in the context of state reinforcement (the importsubstitution industrialization politics of the 1950s), it was aggravated by the rise to power of military juntas in the 1970 s, a decade during which all the countries involved were ruled by nationalist regimes for the first time since the Pacific War. The outcome of this coincidence was far from what may have been expected, however. The generals who headed the governments of Bolivia (General Banzer) and Chile (General Pinochet) opened a seemingly productive dialogue. After meeting, they came to an agreement on Bolivia's land claim, which they celebrated at the famous 1975 abrazo de Charaña, a small locality on the disputed border 
where the men hugged one another. Their proposed solution was to grant Bolivia a corridor to the sea that would be contiguous with the northern border of Chile and enclose the Arica-La Paz railway; Perú, however, refused. Its refusal led to a real crisis, at a time when all the protagonists were about to celebrate the centenary of the outbreak of the Pacific War. ${ }^{20}$ In 1979, both the Chilean and Bolivian armies were mobilized and positioned around the border. Last-minute negotiations prevented war, but Pinochet ordered land mines laid along the border. The border had never been more difficult to cross.

The crisis has eased since then, although the border is still far from being characterized as 'open'. The political transition to democratic regimes in all of the countries involved has helped rebuild dialogue between them. Despite the absence of diplomatic relations between Chile and Bolivia, in the 1990s, their respective consulates were authorized to open new offices of national representation, notably in the Norte Grande cities of Iquique and Arica. Multiple international encounters have also occurred in the last decade, as mentioned above, and whether regional (Comités de Frontera, where the representatives of two provinces meet regularly) or sectorial (meetings on infrastructure, trade, etc.), opportunities for dialogue have been created. They are generally initiated by regional entities, but this does not mean that the whole process is decentralized; many of the regional authorities depend directly on the central power, which monitors these integration processes very closely. When faced with an increasing number of such initiatives, the Chilean Ministry of Foreign Affairs created, in June 2000, a sub-directory unit wholly dedicated to their census and coordination (partially expost), called DICORE (Dirección de de coordinación regional), with the purpose of institutionalizing such processes. Thus, the conditions now exist for an emerging synergy between local, regional and national stakeholders, utilizing a very pragmatic approach. This form of 'inter-democratic' trust does not exclude demonstrations of nationalism, as can be observed in Bolivia, although since the election of Evo Morales as president, the tension 
toward Chile has been handled in a less-rigid way, through mediation that does not exclude future direct negotiations.

This evolution is largely due to the international context of globalisation, which is characterized by the growing integration of markets. The Andean area under consideration is witnessing the construction of various regional markets that are not exclusive of one another. This also illustrates a certain pragmatism in foreign affairs, led largely by Chile. The regions concerned are engaged in pluri-scalar strategies, whereby they can belong simultaneously to APEC, be associated with MERCOSUR and participate in the construction of ZICOSUR (Zona de Integración del Centro Sur de América Latina), which includes the regional representatives of North-West Argentina, the Far North of Chile, Southern Perú, SouthEastern Bolivia and Paraguay. ${ }^{21}$ The rhetoric is totally dominated by an integration discourse. Not only does this promote integration but the theme has been publicized so much that it is now also the sine qua non preamble to any political strategy or initiative.

\section{Figure 2: The ZICOSUR Official Map}

(Source: Chile's II Region / ZICOSUR publications, 1995)

For more maps, see: http://www.zicosur.com/www/php/mapas.php 


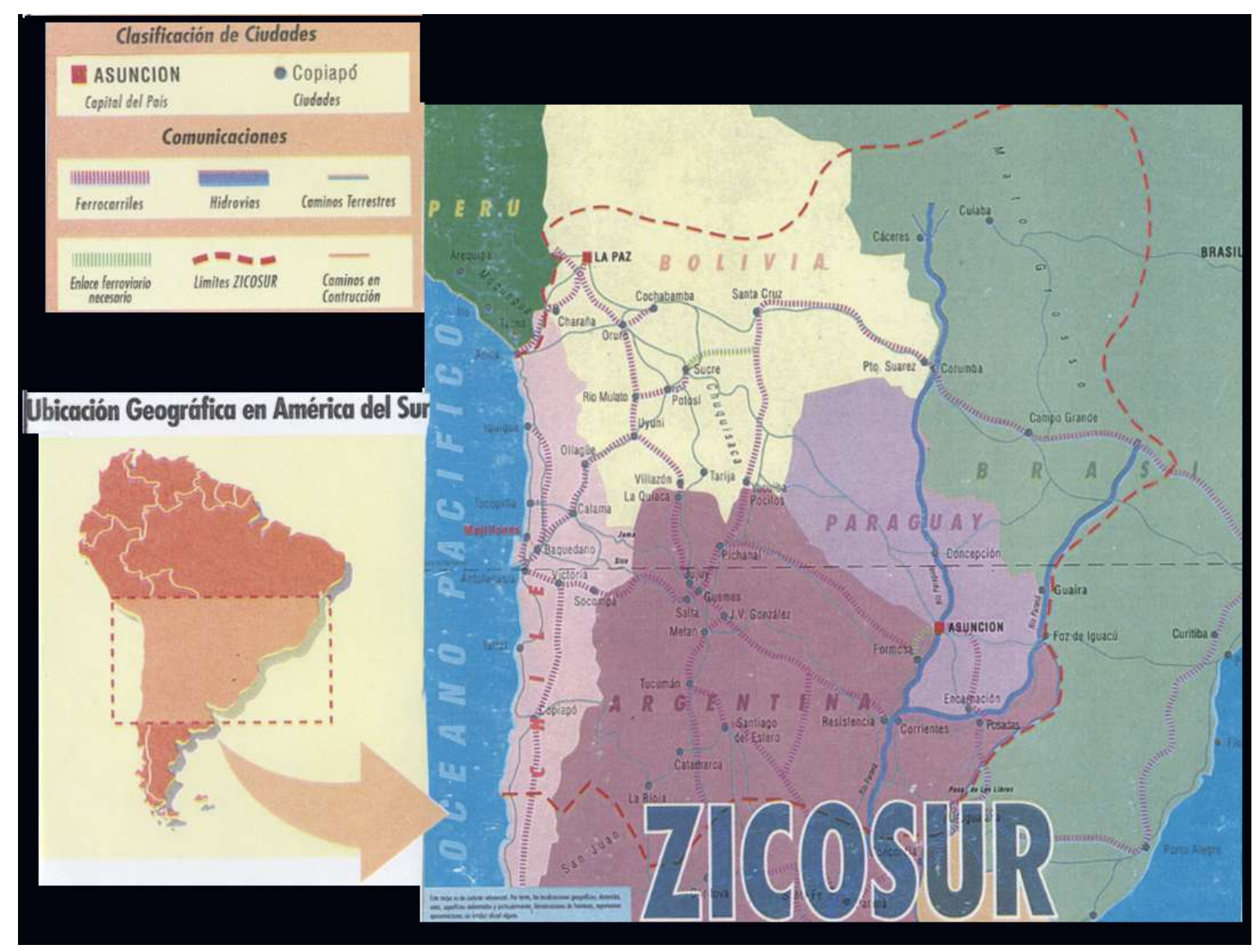

The reality of border transit is very different from the official discourse, however. The period has been largely dominated by the shared wish to control population movement and restrict illegal immigration. The formalities are stricter in the sense that any candidate for crossing must be in possession of identification, whereas before, in some cases, temporary safe conducts existed (they still do between Arica in Chile and Tacna in Perú). The modernization of administrative procedures and the progressive computerisation of entry and exit registries are now reducing the flexibility that inter-human practices allow in small border outposts. Indeed, in the field of human circulation, mobility has never been more tightly controlled than today. As for goods, flows are much more reduced than might be expected, especially since Chile has maintained its high phyto-sanitary barriers, arguing that it cannot risk damaging the stable quality of its products as this allows it to be a large fruit-exporting country. As far as the official management of the border is concerned, boundary reality still 
appears to be very strict, despite the integration rhetoric. The modernization of administrative procedures appears to be, at least in the first phase, the culprit. Currently, a great deal of work is being done to try to harmonize customs and border-patrol practices (consisting of various pilot programs to integrate controls), which denotes the participation of the higher interests that underlie the opening of borders in this zone. However, the day-to-day life of these international borders may not be as rigid as their normative frame: an overview of the configuration of certain customs posts reveals that a Chilean post and a Bolivian post can be close to a kilometre away from each other, which allows all sorts of goods to vanish in between. Considering that high-altitude official control points are also closed at night, it explains why even in times of conflict the borders have never been impermeable. ${ }^{22}$ Historically, periods of intense contact dominate those of isolation, although the present situation should be interpreted in terms of closing down rather than opening up.

\section{MORE TRANSPORTATION BUT LESS MOBILITY?}

The international political context having been detailed, it is easier to understand what is at stake behind the increase in transport infrastructures in this Andean region. In the last decade, the area has witnessed the building of one new harbour, three new roads and two gas pipelines, as well as the beginning of the modernization of its two international railways. This rapid change in the trans-boundary infrastructure map has had a dual role: to satisfy an increasing demand for new transportation infrastructure and to provoke it. In a very liberal context, this assertion may be surprising, but a closer analysis of the way in which some elements of this new infrastructure were built reveals a good deal of deliberateness- not to mention planning — in their design. ${ }^{23}$

This is not easy to prove, however, since nothing is more difficult to quantify than flows, which are by their labile nature difficult to grasp at a fixed point. The reference data consist of figures collected at customs houses, but the real numbers are probably much higher, as can be inferred from the present functioning of boundary controls, as noted above. Flows of 
goods increased considerably in the 1990s, with more exports than imports, which validates the hypothesis that the Chilean coast plays a redistributive role for a bigger hinterland (this is especially the case for road traffic; train-flow patterns are slightly different). In the case of newly asphalted roads, the volume of goods exchanged grows rapidly from the moment the quality of the road changes. For the Arica-La Paz highway that passes the Chungara customs house, the years 1995 and 1996 were fundamental (merchandise going out of Chile increased from $200,000 \mathrm{t} / \mathrm{year}$ at the beginning of the $1990 \mathrm{~s}$ to between 350,000 and $380,000 \mathrm{t} / \mathrm{year}$ at that crucial moment, and by the year 2000 had stabilized at around 500,000 t/year); for the Jama Pass road between Chile and Argentina, the year 2000 was essential (from less than $20,000 \mathrm{t} /$ year in the early 1990 s to between 50,000 and $60,000 \mathrm{t} /$ year by mid-decade and more from 2000 onward, with as much as 95,000 $\mathrm{t}$ in 2003).

This evolution was not only linked to the quality of roads, however, as was revealed by a traffic analysis in Colchane, the customs point between Iquique and Oruro, which is on a bad road. Outgoing merchandise grew from approximately 10,000 t/year in the early 1990 s to $50,000 \mathrm{t}$ in $1993,90,000 \mathrm{t}$ in 1995-96, 112,000 $\mathrm{t}$ in $1998 \mathrm{and}$, after a sudden collapse, 60,000 $\mathrm{t}$ in 2003. This increase in traffic is linked to the expansion of the Iquique duty-free zone (Zona Franca de Iquique, ZOFRI) whose imports are largely intended for the Bolivian (and Paraguayan) markets. According to customs officers in Colchane, about 30 vehicles cross the border daily, about 15 of which declare their goods. This data suggest that commercial routes do not only follow those favoured by public policy.

The official transportation policy tends to federate efforts in order to include all existing infrastructure into continental 'corridors' that could sustain the development of an integrated economy on a hemispheric scale. The term used in Spanish is corridor bioceánico and refers to a set of trunk routes (road and rail) that, put together, would serve as a continental infrastructure that would allow South America to be crossed and link the Pacific and Atlantic oceans. This notion has been promoted since the early 1990s, although the 
concept existed in the first economic-integration documents that were developed in the 1960s. It has led to a vast production of maps, to which few geographers are indifferent due to their striking use of the suggestive power of line drawing. Most of these maps represent both existing and planned infrastructures in the same colour, which leads most readers to deduce that all of these connections already exist (see Figure 5 or $<\underline{w w w}$.iquique.co.cl/iquique.htm $>$ 'integration' tab, for a sample). Many regional stakeholders, however, are endeavouring to build their own corridors, regardless of more collaborative actions. An analysis of the municipal strategies of Chilean towns has shown that what is essential for each of them is not so much to build a good connection to the continental route but rather to promote a new international highway that would have their town situated at the beginning of it. Thus, corridor projects can multiply.

Figure 3: A Continental Map of Bi-oceanic Corridors (http://www.iirsa.org) 


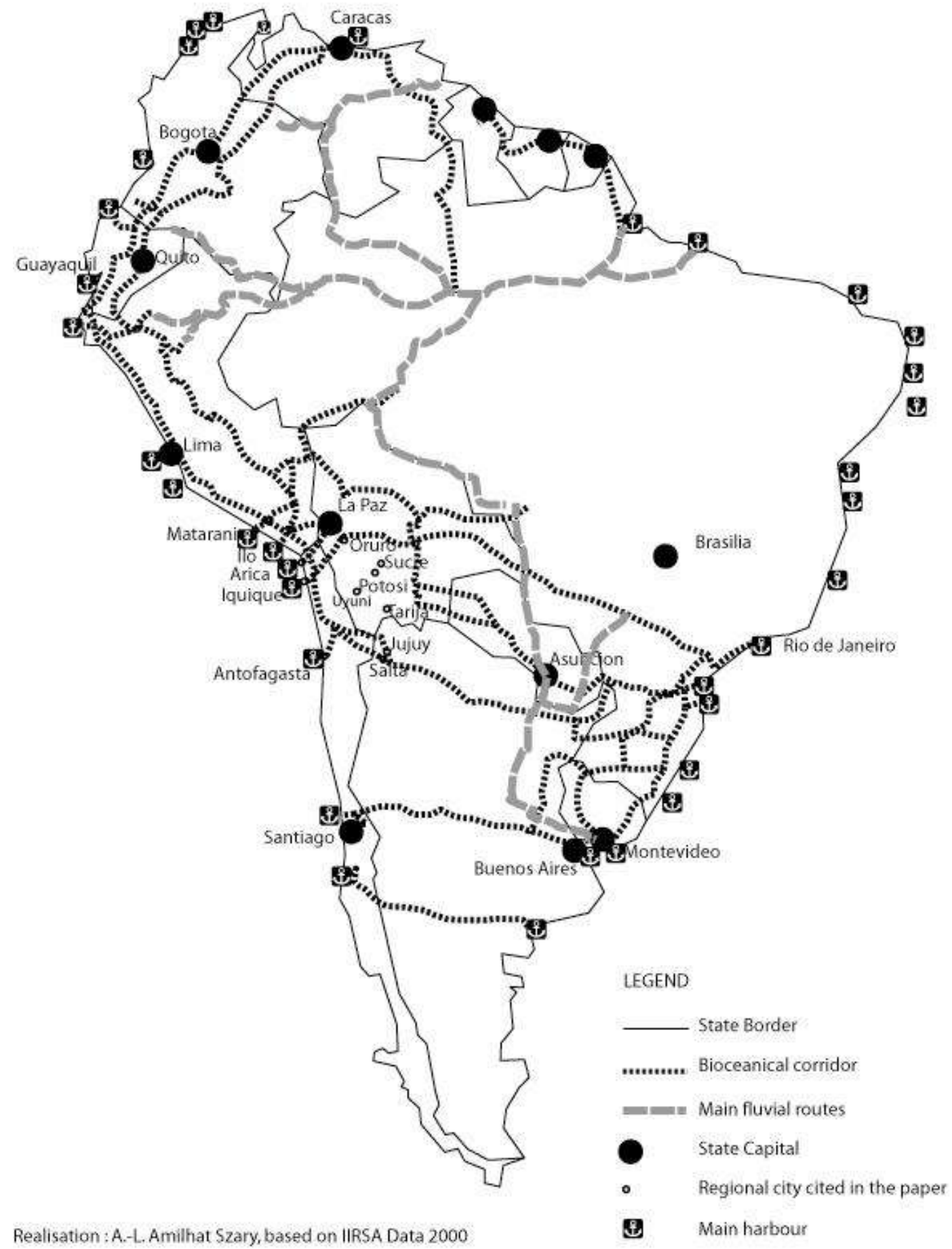


Given the inflation of projects, it is difficult to classify the use of different routes in terms of individual and collective passenger traffic. The only direct passenger traffic through the Andes is by bus; there are no direct plane links between the regional capitals, except during the summer tourist season. The stakeholders who meet regularly to build the integration process discussed here must take connecting flights, which usually means flying back to the capital city and out again and therefore covering thousands of additional kilometres. Most of the traffic involves local truck companies, many of them owned by indigenous entrepreneurs, and an analysis of this is currently underway. Based on the first results of this analysis, it appears that passenger traffic is increasing but only that devoted to trade, and it is not being followed by other types of movement (for leisure, family visits, tourism, etc.). This sectorial reading has to be deciphered: not all of those who would like to cross the Andean borders are allowed to do so, a reality that derives in large part from smuggling, based on national or regional differentials (traditional Bolivian migration to Argentina and Peruvian migration to Chile coexist with regional flows, notably between Southern Bolivia and Northern Chile). Despite Chile's interest in an inexpensive workforce (even if local wages are respected, employers who contract with illegal foreign workers do not pay a social-security contribution), local governments are currently initiating an analysis of the social aspect of continental integration. In this effort, some of the concerned regions may be allowed to play an innovative role through the local adaptation of work contracts. In order to complement their analysis, this present research has been dedicated to a more quantitative approach to mobility studies in the Andes. To investigate the political integration process, it is necessary to focus on the movement patterns of the regional elite, understood as the group of stakeholders (from the public and private sectors) that express direct interest in this process.

\section{CONCLUSION}

In this paper, a case study has been assembled to qualify the notion of 'opening up' borders. The first nuance was revealed by the necessary construction of a proper reference horizon. In 
the Andean case, contemporary discourses speak of open borders as a new process, yet a historical overview shows that in the past thousand years, the moments when borders were closed have been the exception rather than the rule. The second series of restrictions concerns the conditions of mobility on de-functionalized boundaries. Although a decision may be taken to open borders, it takes a very long time before habits change in borderland regions; moreover, in modern and technological states, there may be a phase when new forms of control (supposedly serving open borders), being more efficient than those that served closed borders, limit trans-border flows. The third limitation is the necessary confrontation with the evolution of movement around the border. It is commonly observed that the withdrawal of barriers does not necessarily imply a proportionate growth in all types of movement. Passenger traffic is subjected to a scalar effect: if long-distance crossings (100 km or more, i.e., between two piedmont cities) increase considerably, short trips and near-by movements (those that can be covered, both ways, in a day) can be directly affected by the border-opening process. This may only be a first phase, followed by an improvement in trans-boundary circulation; thus, one must be careful not to generalize from this case.

The Andean example and the Bolivian crisis have also illustrated the return of an old territorial dispute, due to the reactivation of movements and exchanges that appear to be important geopolitical factors. The crisis seemed to have been forgotten while the concerned area was enduring a long economic recession; now that the zone has the potential to be integrated into the global economy, rival interests are expressing themselves. Interestingly enough for the geographer, this reveals two contrasting conceptions of territory at work: one conceives territory as the expression of political power, while the other defines territory as the extension of economic influence and exchange. From this perspective, the border itself appears to be as much as a resource as the flows of people and merchandise that transit through it. 
This study of such peripheral dynamics was intended to allow innovative territorial patterns to stand out. The overall process of subcontinental integration described here is original per se, since it mainly originates in a bottom-up process where the regions involved have managed to aggregate themselves to national and continental agendas. Throughout the analysis, various processes have been characterized as breaking novel ground, in administrative and legislative matters (work contracts, for example), as well as in economic evolutions (indigenous entrepreneurship or the proliferation of regional commercial fairs). Moreover, this case study has allowed a formulation of a new hypothesis of geopolitical analysis concerning power analysis: the stakeholder analysis undertaken in this study reveals the outstanding role played by the private sector (in a perpetual negotiation between regional and transnational firms) and by the weight of territorial units (regions, provinces, municipalities or associations of the latter entities) in the regional geopolitical balance. The conflict between Bolivia and Chile, an ongoing current event and the most frequently mentioned in Latin American news, cannot be understood without taking into account the para-diplomacy described here and the economic vision of territory of some of the influential stakeholders of the area, in contrast to a simplified nationalist discourse.

\section{NOTES}


'. P. Andreas and T. Snyder (eds.), The Wall around the West: State Borders and Immigration Controls in North America and Europe (Lanham, MD : Rowman \& Littlefield 2000).

2. J. Anderson, L. O’Dowd, et al. (eds.), 'New Borders for a Changing Europe. Cross-border Cooperation and Governance', Regional and Federal Studies 12/4 (winter 2002) p. 4.

${ }^{3}$. Les frontières de la France (Paris: Hachette 1947), quoted by M. Anderson, 'The Transformation of Border Controls: A European Precedent?', in P. Andreas and T. Snyder (eds.), The Wall around the West. State Borders and Immigration Controls in North America and Europe (Lanham, MD: Rowman \& Littlefield 2000).

${ }^{4}$. M. Foucher, Fronts et frontières. Un tour du monde géopolitique (Paris: Fayard 1991).

5. J. Siles Guevara, Le droit bolivien au Pacifique (La Paz: Commision nationale pour la remémoration de la Guerre du Pacifique 1980) p. 103.

${ }^{6}$. J. Tapia Valdés, 'Paradiplomacia: las relaciones internacionales de los órganos subregionales de gobierno. El marco juridico-institucional de la integración transfronteriza subregional', in El marco jurídico-institucional de la integración transfronteriza subregional (Iquique: UNAP, Instituto de Estudios Internacionales 2003) pp. 113-22.

7. A.-L. Amilhat Szary, 'L'intégration continentale aux marges du MERCOSUR: les échelles d'un processus transfrontalier et transandin', in Revue de Géographie Alpine 91/3 (2003) (Special issue 'Traverser et utiliser la frontière, Andes-Alpes').

${ }^{8}$. C.F. Bergsten, 'Open Regionalism', The World Economy 20 (August 1997) pp. 545-65;

S.-J. Wei and J.A. Frankel, 'Open Regionalism in a World of Continental Trade Blocs', International Monetary Fund Staff Papers 45/3 (1998) pp. 440-53; M. Kuwayama, Open Regionalism in Asia Pacific and Latin America: A Survey of Literature (Santiago: CEPAL, International Trade and Development Finance Division 1999) p. 71; N. Phillips, 'The Rise and Fall of Open Regionalism? Comparative Reflections on Regional Governance in the Southern Cone of Latin America', Third World Quarterly - Journal of Emerging Areas 24/2 (2003) pp. 217-34; E. Gudynas, El 'regionalismo abierto' de la CEPAL: insuficiente y confuso (Silver City, NM: IRC [International Relations Center]/Programa de las Américas 2005). 
9. Free-trade agreements signed first with Canada in 1996 and then with Mexico, Central America, the Republic of Korea, the EFTA, the EU and the US, as well as Economic Complementation Agreements (Acuerdos de Complementación Económica), which are basically first-generation market access agreements (with Bolivia, Colombia, Cuba, Ecuador, MERCOSUR, Peru and Venezuela).

${ }^{10}$. A. Aranibar Quiroga, 'Memoria corta de un antiguo diferendo', Nueva Sociedad 190 (2004) pp. 4-13.

${ }^{11}$. With the discovery of the second-largest gas reserves in South America in the Tarija province in the mid-1990s, a political debate arose on the difficulties of their exploitation. Would they be developed for internal or external needs? And if destined for export, by which route should they reach the Pacific? In the liberal context of the turn of the $21^{\text {st }}$ century, the operation was given first to a consortium called Pacific LNG, formed by the British companies British Gas and British Petroleum and the Spanish Repsol-YPF. Then in 2002-03, various presidents (Jorge de Quiroga, followed by Sánchez de Lozada) proposed a pipeline be constructed toward the Chilean harbour at Mejillones, rather than a Peruvian one, although this meant co-operating with the historical enemy instead of allying with friendly Peru. Rioting erupted in October 2003 and forced Sánchez de Lozada to resign. His successor, Carlos Mesa, promised a referendum on the topic but did not succeed in matching liberal convictions with the nationalist claims of the capital's population. The gas war is one of the main factors in the dazzling political ascension of indigenous leader Evo Morales, who became Bolivia's new president following the 2005 elections. For more information, see L. Perrier Bruslé and J.-C. Roux, 'Les enjeux géopolitiques du gaz en Bolivie. Entre mondialisation et souveraineté perdue', Annales de Géographie 630 (2003) pp. 169-87.

12. S. Gonzalez Miranda, Chilenizando a Tunupa. La escuela pública en el Tarapacá andino 18801990 (Santiago: DIBAM/UNAP/IEA/CIDBA 2002) p. 292.

${ }^{13}$. C. Troll, Die geographische Grundlagen der Andinen Kulturen und des Inkareiches', IberoAmerikanisches Archiv 5 (1931) pp. 258-94; J.V. Murra, Formaciones económicas y políticas del mundo andino (Lima: IEP1975) p. 339; J.V. Murra, 'El “Archipiélago Vertical” Revisited', in S. 
Masuda, I. Shimada and C. Morris (eds.), Andean Ecology and Civilization. An Interdisciplinary Perspective on Andean Ecological Complementarity (Tokyo: U. of Tokyo Press 1985); J.V. Murra, 'Le contrôle vertical d'un nombre maximum d'étages écologiques et le modèle en archipel \& Quinze ans après, un bilan de la notion d'archipel', in P. Morlon (ed.), Comprendre l'agriculture paysanne dans les Andes Centrales. Pérou - Bolivie (Paris: INRA 1992), pp. 124-40.

${ }^{14}$. G. Cortès, Partir pour rester. Survie et mutation des sociétés paysannes andines (Bolivie) (Paris: IRD 2000) p. 413 ; G. Cortès, 'Migrations et mobilités circulatoires dans les Andes boliviennes. La face cachée d'une ruralité en «résistance »', C.M.H.L.B. Caravelle 79 (2002) pp. 93-115.

${ }^{15}$. Nuñez and Dillehay have established a historical typology of these mobilities, according to the extension of networks and their degree of complexity. Following the 'exploratory' period, it distinguishes the following phases:

- 1800-900 BC: transition or initial mobility phase, characterized by prolonged contacts between the human groups of the Altiplano and its surroundings, through regular caravans;

- $900 \mathrm{BC}-500 \mathrm{CE}$ : population increases and caravan routes begin to converge around Lake Titicaca, the most important agro-pastoral production zone. From 200 BC, the Tiwanaku area acquires a polarizing effect;

- 500-1400 CE: all networks converge in Tiwanaku, where social and economic alliances have preceded the emergence of strong, local religious patterns. The conjunction of religious influence and trade seems to have led to the first integration mechanism in the central Andes. The latter does not suffer too much from the diminishing influence of the Tiwanaku civilisation.

- 1500-1525 CE: Inca occupation, based on the existing networks, which it improves, notably by building paved routes.

L.Nuñez Atencio and T. S. Dillehay, Movilidad giratoria, harmonía social y desarrollo en los Andes meridionales : patrones de tráfico e interacción económica (Antofagasta, Chile: Universidad Católica del Norte 1995) p. 190. 
${ }^{16}$. V. Conti, 'Las ferias cómo articuladores regionales en el siglo XIX', Cuadernos. Univ. Nacional de Jujuy, Facultad de Humanidades y Ciencias Sociales 1, (1989) pp. 106-18; S.E. Mata, 'Circuitos comerciales e integración del espacio andino; Salta en la segunda mitad el siglo XVIII', Cuadernos. Univ. Nacional de Jujuy, Facultad de Humanidades y Ciencias Sociales 1 (1989) pp. 92-105; V. Conti, 'El Norte argentino y Atacama: los circuitos mercantiles como elemento de integración

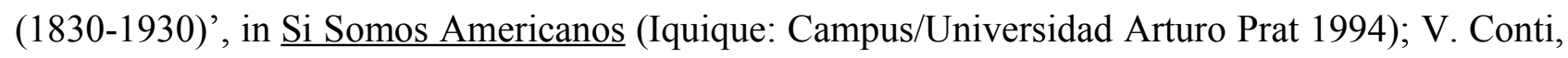
'La ruta de los arrieros y el salitre', in El capricornio andino (Santiago: Monumentos nactionales de Chile 2000) chap. 7; V. Conti, 'Los comerciantes de Salta en los puertos del Pacífico 1840-1870', $\underline{\text { Revista de Estudios Trasandinos }} 4$ (2000) pp. 131-46; V. Conti and M. Lagos (eds.), Una tierra y

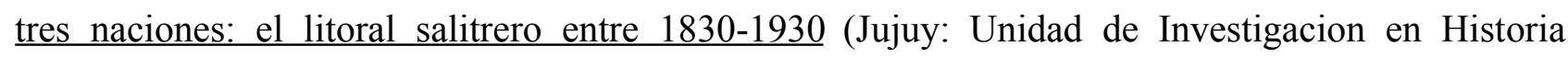
Regional, Facultad de Humanidades y Ciencias Sociales, Universidad Nacional de Jujuy 2002).

${ }^{17}$. For a chronology of reconstitution attempts, see J.A. González Pizarro, 'Esquema de periodificación histórica de las relaciones entre el Noroeste argentino y el Norte de Chile', $\underline{\text { Revista }}$ de Estudios Trasandinos 4 (2000) pp. 97-115.

${ }^{18}$. S. González Miranda, 'L'origine du Norte Grande du Chili: Frontières ouvertes, mentalités fermées', Revue de Géographie Alpine 91/3 (2003) pp. 11-27.

19. After World War I, nitrate exploitation was threatened by the invention of chemical fertilizers, and the economic crisis of the 1930s dealt the Chilean industry its deathblow.

${ }^{20}$. A. Benavides Correa, Habrá guerra próximamente en el cono sur ...? América Latina: explosiva caldera geopolítica (Mexico: Siglo Veintiuno Editores 1974) p. 170.

${ }^{21}$. A.-L. Amilhat Szary, 'Les recompositions du Norte Grande chilien pendant la transition démocratique: enjeux d'une gestion territoriale en contexte néolibéral', Revue de Géographie Alpine 88/1 (2000); A.-L. (Amilhat) Szary, La région, paradoxe territorial néolibéral? Analyse de l'impact géographique d'un modèle économique sur le Norte Grande chilien, Ph.D. (Toulouse: Université de Toulouse Le Mirail, UFR Géographie 1999), p. 509.

22. L. Juge, Mobilité, frontière et territoires commerçants dans les Andes Centrales, Master Thesis (Grenoble: UJF, IGA 2003 ) p. 85. 
${ }^{23}$. J. Petit, 'Les territoires de passage à l'épreuve des aménagements transfrontaliers dans les Andes de la Puna', Revue de Géographie Alpine 91/3 (2003) pp. 71-91. 